\title{
Landfill Impacts on Groundwater Quality: Consideration of Three Case Studies
}

\author{
Nimad Felegari ${ }^{1, *}$, Hasti Hasheminejad ${ }^{2}$ \\ ${ }^{1}$ MS student, Dept. of Civil Engineering, Isfahan Univ. of Technology (corresponding Author). \\ ${ }^{2}$ Assistant Professor, Dept. of Civil Engineering, Isfahan Univ. of Technology
}

\begin{abstract}
The social and environmental impacts imposed by municipal solid waste (MSW) received attention in recent decades. The impact of landfill leachate on the groundwater has given rise to a great number of studies in recent years. The main purpose of this study is identify the most characteristics of pollutant in groundwater caused by municipal solid waste sites. As another important goal is consider common pollutant in this sites and identify some main source of pollution which is same among this sites.

The samples were analyzed for physiochemical properties as well as for major ion concentrations such as $\mathrm{Ca}^{2+}$, $\mathrm{Mg}^{2+}, \mathrm{Na}^{+}, \mathrm{K}^{+}, \mathrm{NH}_{4}^{+}, \mathrm{Fe}^{2+}, \mathrm{Mn}^{2+}, \mathrm{Cl}, \mathrm{SO}_{4}^{2-}, \mathrm{HCO}_{3}^{-}$and another heavy metals and ions. the results show that, the concentrations of these ions and heavy metals exceed the permissible concentration in groundwater. Another results show that the main source of some ions such as $F$ (fluoride) had a geochemical source present in the aquifer and the further existence concentrations of $\mathrm{NO}_{3}{ }^{-}$shows that agricultural activities have also extensively influenced the groundwater quality.
\end{abstract}

Keywords: Leachate, MSW, permissible concentration, geochemical source.

\section{1 .Introduction}

The generation of solid waste has become an increasing environmental and public health problem everywhere in the world, particularly in the developing countries. The rapid expansions of urban, industrial and commercial activities prompted by rapid population growth are the major cause for producing huge amounts of solid wastes [2]. Pollutants in water are comes from natural and anthropogenic sources. As a natural example, it should be noted the widespread arsenic contamination of groundwater in East and South-East Asia. There are many anthropogenic source of water pollution. First of all, it is untreated effluents of industrial enterprises in the water. Another water pollution which we can mention is local, targeted sources of contamination of soil and groundwater in municipal solid waste storage sites where the leachate seeping through soil, get into the soil and groundwater[1]. Landfill leachate is generated when excess rainwater percolates through the waste layers in a landfill. Landfill leachate may be categorized as a water-based solution of four groups of contaminants (dissolved organic matter, inorganic macro-components, heavy metals, and xenobiotic organic compounds. The most important potential environmental influences associated with landfill leachate are contamination of groundwater and surface water. Groundwater is a worldwide significant and valuable renewable resource for human life and economic growth. Groundwater pollution is principally due to the process of industrial development and urbanization that has gradually developed over time without any esteem for environmental significances [3]. So the groundwater pollution at landfill sites become more important issue in environment subjects.

Currently, sanitary landfill represents a viable and the most commonly used method for solid waste disposal all over the world because it may achieve the reclamation of derelict land. Also, properly designed and operated sanitary landfills eliminated some adverse environmental impacts that result from other solid waste final disposal alternatives such as burning in open-air burning sites and open-pit dumping. However, other impacts may arise from gas and leachate formation if not well controlled. These impacts include fires and explosions, vegetation damage, unpleasant odors, landfill settlement, groundwater pollution, air pollution and global warming. In developing countries, landfills have been largely unsuccessful because the landfills site a very limited time frame 
of usage [4]. Contamination phenomena for MSW landfills are almost exclusively associated with the presence of ammonia, chlorides, COD, sulphates, iron and some heavy metals. When the above substances are detected in groundwater downstream of a landfill by environmental protection authorities, frequently no further analyses are carried out, and the landfill is automatically the cause of contamination. This technical and, above all, negative psychological approach may however generate gross scientific errors loading to other potential cause being overlooked. Indeed, we live in a world in which gas, liquid and solid emissions which are causing a constant deterioration in environmental quality throughout the planet are continuously produced. These emissions are broadly associated with our life styles (transport, heating and air-conditioning, energy production, agriculture and zootechnics, industrial production etc.) [5]. In this study we reviewed the most groundwater pollution cause of landfill sites in different studies, in order to:(i) better understand the possible impact of leachate percolation on groundwater quality and evaluate the potential sources of inorganic pollutants and the extent of the contamination, (ii) better understand the common pollution in groundwater near landfills site and their common sources.

\section{The sources and composition of the leachate from landfills}

Such important properties of solid waste landfills are excreting [1]:1. Dumps are heterogeneous, both in area and volume, 2. Landfills contain a mixture of inorganic and organic pollutants, 3. The landfill can allocate pollutants for tens and hundreds of years.

Landfill size usually varies from a few hectares to more than 50 ha. The value of landfill can vary from 100,000 to 5,000,000 cubic meter. Water soluble pollutants from municipal landfills can be divided into four groups [1]:

1. Water-soluble and oxidable by oxygen, organic substances including, methane and volatile fatty acids.

2. Inorganic macro components: $\mathrm{Ca}^{2+}, \mathrm{Mg}^{2+}, \mathrm{Na}^{+}, \mathrm{K}^{+}, \mathrm{NH}_{4}^{+}, \mathrm{Fe}^{2+}, \mathrm{Mn}^{2+}, \mathrm{Cl}^{-}, \mathrm{SO}_{4}^{2-}, \mathrm{HCO}_{3}^{-}$.

3. Heavy metals: cadmium $\left(\mathrm{Cd}^{2+}\right)$, chromium $\left(\mathrm{Cr}^{3+}\right)$, cooper $\left(\mathrm{Cu}^{2+}\right)$, lead $\left(\mathrm{Pb}^{2+}\right)$, nickel $\left(\mathrm{Ni}^{2+}\right)$, zinc $\left(\mathrm{Zn}^{2+}\right)$.

4. Organic xenobiotics, falling from household and industrial chemicals. The concentration of each of them is less than $1 \mathrm{mg} / \mathrm{l}$. they are represented by different aromatic hydrocarbons, pesticides, medicines.

In the table 1[1] shows the interval content of pollutants in landfill leachate, obtained through a large number of literary data on landfill sites younger than 25 years. As can be seen from the table 1, contents of dissolved organic matter and inorganic pollutants can reach very high values: 10-500 times above background values[1].

\begin{tabular}{|c|c|}
\hline Parameter & Range \\
\hline $\mathrm{pH}$ & $4.5-9$ \\
\hline Conductivity (MS/sm) & $2500-35000$ \\
\hline Solid residue & $2000-60000$ \\
\hline Total content $\mathrm{C}$ org & $30-29000$ \\
\hline Organic nitrogen & $14-2500$ \\
\hline Total content $P$ & $0.1-23$ \\
\hline Chlorides & $150-4500$ \\
\hline Sulfates & $8-7750$ \\
\hline Bicarbonate & $610-7320$ \\
\hline $\mathrm{Na}$ & $70-7700$ \\
\hline $\mathrm{K}$ & $50-3700$ \\
\hline Ammonium (N) & $50-2200$ \\
\hline $\mathrm{Fe}$ & $3-5500$ \\
\hline Mn & $0.03-1400$ \\
\hline $\mathrm{Cu}$ & $0.005-10$ \\
\hline $\mathrm{Pb}$ & $0.001-5$ \\
\hline $\mathrm{Ni}$ & $0.015-13$ \\
\hline $\mathrm{Zn}$ & $0.03-1000$ \\
\hline
\end{tabular}




\section{Consideration of Three Case Study}

For better understanding we should consider three case studies which can help us to figure out the influence of leachate on groundwater pollution.

\subsection{Case A.}

In this case study we reviewed the assessment of groundwater quality in and around the Jawaharnagar Municipal Solid Waste Dumping Site at Greater Heyderabad, Southern India which evaluated the various indices to understand the hydro geochemistry of groundwater in the study area. Physicochemical such as pH, EC, TDS, major anions, cations and toxic metals were included for discussion. Results show that the $\mathrm{pH}$ value is with an average of 7.04 exceeding from the standards prescribed for compost in Municipal Solid Waste (Management and Control). This may be due some basic contents in the waste. However, its higher range accelerates the scale formations in water heating apparatus either in industrial or domestic purposes. The average EC value is 897 $\mu S / \mathrm{cm}$ while average TDS value $1589 \mathrm{mg} / \mathrm{L}$ is observed. From the data of alkalis $\left(\mathrm{Na}^{+}, \mathrm{K}^{+}\right)$and alkaline earths $\left(\mathrm{Ca}^{2+}, \mathrm{Mg}^{2+}\right)$, reveal that high concentration of $\mathrm{Ca}^{2+}$ than others with following order $\mathrm{Ca}^{2+}>\mathrm{Na}^{+}>\mathrm{Mg}^{2+}>\mathrm{K}^{+}$. Among the various anions determined in groundwater samples, $\mathrm{HCO}_{3}{ }^{-}, \mathrm{Cl}^{-}, \mathrm{SO}_{4}{ }^{2-}$ are the major anions identified in the groundwater $\left(\mathrm{Cl}^{-}>\mathrm{HCO}_{3}{ }^{-}>\mathrm{SO}_{4}{ }^{2-}\right)$. This could be due to available carbonates in the rocks might have been dissolved and added to the groundwater system during irrigation, rainfall infiltration and groundwater movement increase the bicarbonate. Further, an increased chloride concentration may be due to the process of the removal of other ions from the system as sampling done during post monsoon, either by precipitation or by adsorption. The high content of chloride in water causes salinity related problems. Total hardness (TH) of groundwater samples in the present study exhibited minimum content of 120 to a maximum of $525 \mathrm{mg} / \mathrm{L}$ with an average of $290 \mathrm{mg} / \mathrm{L}$. (note: the maximum allowable limit of $\mathrm{TH}$ for drinking water is $500 \mathrm{mg} / \mathrm{L}$ and the most desirable limit is 100 $\mathrm{mg} / \mathrm{L}$ as per the WHO standard.) The spatial distribution of hardness shows higher concentrations were observed in the central part of the study area. Heavy metal are the major indicator of anthropogenic impact which having various sources like dry deposition from incineration plants, industrial effluents traffic activities and landfill leachate etc. Therefore monitoring of heavy metals which are toxic in nature are concern to assess the landfill impact on groundwater quality. The results of metal analysis of groundwater reveal that all the toxic metals are nearly falls within the prescribed standard except $\mathrm{Mn}$ in few samples. The low concentration is perhaps due to its requirement for several microbial enzymatic activities. It appears that there is no indicator compounds that is unique to landfill leachate which is not presented in uncontaminated water [2].

\subsection{Case B.}

In this case study we reviewed the assessment of groundwater quality which polluted with leachate from closed landfill site in the Dhapa, Kolkata, India. The $\mathrm{pH}$ value of the collected leachate was significantly alkaline. The concentrations of EC and TDS of the collected leachate were high. The high concentration of EC and TDS can be attributed to the presence of inorganic components, mainly high levels of various anions and the soluble salts. Total hardness( $\mathrm{TH})$ in the leachate samples might have been caused by multivalent cations particularly calcium and magnesium. High concentrations of chloride were found in the leachate sample. The high chloride value justifies high range of TDS and COD value in the present case study. For leachate sample, sulphate concentration was high and it might be due to the presence of different inorganic waste materials. Phosphates might have a variety of sources including agricultural fertilizers, domestic waste, detergents, industrial process wastes etc. High range of ammoniacal nitrogen was obtained in leachate sample. In the case of groundwater samples, $\mathrm{pH}$ was within the acceptable range of drinking water standards. The value of EC was high in collected groundwater samples. The high values of EC of groundwater sample indicate higher concentration of anions and cations. The TDS values of the groundwater samples were far above the permissible limit. High TDS values leads to objectionable taste, odor and color in water. The TH values were obtained above the permissible limit. The total hardness concentration of groundwater was high and may be due to faintly alkaline state. $\mathrm{Cl}^{-}$concentration were 
above the permissible limit. The pollution sources for $\mathrm{Cl}^{-}$might be due to domestic effluents, fertilizers, and leachates. $\mathrm{SO}_{4}{ }^{2-}$ concentrations were well below the permissible limit [3].

\subsection{Case C.}

In this case study we reviewed the assessment of groundwater quality which polluted with leachate from a municipal landfill site in Zhoukou city, Henan province, China. The temperature of all water samples ranged from 7.6 to $22.7^{\circ} \mathrm{C}$. The groundwater was characterized by the $\mathrm{pH}$ values from 6.61 to 8.94 . groundwater was characterized by low turbidity $(0.1-1.9$, mean value of 0.7$)$ in the winter season and high turbidity $(0.9-17.2$, mean value of 5.9) in the summer season. Sewage water and leachate samples recorded a much higher turbidity of 79.290.1 NTU with a mean value of 84, suggesting that they may have more influence on local groundwater during the summer season. To some extent, turbidity can reflect the degree of contamination or leachate influence in different water bodies. A wide range of electrical conductivity values $(369-4000 \mu \mathrm{S} / \mathrm{cm})$ indicate presence of either contamination by leachate (expected to have high salinity), and/or evaporation of groundwater prior to/during recharge. $\mathrm{COD}_{\mathrm{MN}}$, (expressed in oxygen $\mathrm{mg} / \mathrm{L}$ ), can be regarded as an aggregative indicator reflecting the extent of groundwater pollution by organic and reducing inorganic matter. The presence of relatively high $\operatorname{COD}_{\mathrm{MN}}(\mathrm{range}$ of $0.08-46.7 \mathrm{mg} / \mathrm{L}$, leachate $=40.3 \mathrm{mg} / \mathrm{L}$ ) in the collected groundwater samples near the landfill indicates the threat of severe contamination of groundwater. Groundwater salinity in the summer season (mean TDS concentration of $1.29 \mathrm{~g} / \mathrm{L}$ ) was higher than in winter season (mean of $0.97 \mathrm{~g} / \mathrm{L}$ ), indicating greater amounts of leachate generated in zhoukou landfill in summer, which could be attributed to the rising water table and subsequent mixing of leachate with groundwater nearby. Some evaporative effects in summer may also be responsible for the higher TDS contents. Fluoride ( $\mathrm{F}^{-}$) concentrations in groundwater are range from 0.02 to 4.19 $\mathrm{mg} / \mathrm{L}$ (mean value of $0.93 \mathrm{mg} / \mathrm{L}$ ). The $\mathrm{F}^{-}$concentrations in $33 \%$ of groundwater samples exceeded the drinking standard of $1 \mathrm{mg} / \mathrm{L}$. The majority of groundwater samples were collected from the shallow aquifer (less than 30 meter depth), and nitrate $\left(\mathrm{NO}_{3}{ }^{-}\right)$concentrations ranged from 0.1 to $487 \mathrm{mg} / \mathrm{L}$ (mean value of $59 \mathrm{mg} / \mathrm{L}$ ) with $43 \%$ of these samples exceeding the Chinese standard of $20 \mathrm{mg} / \mathrm{L} \mathrm{NO}_{3}{ }^{-}$. Nitrate could not be detected in the sewage water nor the leachate. This indicates that local agricultural activities (e.g. the use of $\mathrm{N}$-fertilizers with precipitation infiltration or irrigation return flow) are the primary cause of the extensive groundwater nitrate concentration, as opposed to any point source nitrate contamination from the landfill site. There is no significant negative correlation between $\mathrm{NO}_{3}{ }^{-}$and $\mathrm{HCO}_{3}{ }^{-}$, indicating little or no heterotrophic denitrification, which would otherwise continuously remove nitrate from the aquifer. $\mathrm{Ca}^{2+}, \mathrm{Na}^{+}$are the most abundant cations in the groundwater with concentrations of 30.2-872.0 mg/L (mean value of $175.6 \mathrm{mg} / \mathrm{L}$ ) and 13.7-212.6 mg/L (mean value of $69.9 \mathrm{mg} / \mathrm{L}$ ), respectively. Additionally, the highest concentrations of $\mathrm{Ca}^{2+}, \mathrm{Mg}^{2+}$ were found within the shallow aquifer. This indicates that higher concentrations of these cations may be caused by leakage of landfill leachate into the groundwater. The high $\mathrm{Mg}^{2+}$ concentrations around the landfill may result due to industrial waste like cosmetics, cement and textiles are being dumped into the landfill [6].

\section{Conclusion}

As we discussed above, the important source of drinking water is groundwater and humans consciously or unconsciously cause the pollution in them and very important pollutant cause by human is resulted from landfill sites which contain many kind of pollutants. Solid domestic waste is one of the most important source of pollution landfills, where the leachate seeping through soil, gets into soil and groundwater. The number of contaminated leachate depends both on the amount of stockpiled wastes and geographical location [1]. As we discussed above, groundwater quality assessment studies around Jawaharnagar municipal solid waste dumping site indicating that the pollution source is dominated over natural process in the vicinity of studied area. However the excess nitrate contamination is expected due landfill activities [2]. The analysis of $\mathrm{NO}_{3}{ }^{-}$concentration distribution shows that agricultural activities (e.g. the use of $\mathrm{N}$-fertilizers) have also extensively influenced the groundwater quality [6]. Among the various anions determined in groundwater samples, $\mathrm{HCO}_{3}{ }^{-}, \mathrm{Cl}^{-}, \mathrm{SO}_{4}{ }^{2-}$ are the major anions identified in the groundwater. This could be due to available carbonates in the rocks might have been dissolved and added to 
the groundwater system during irrigation, rainfall infiltration and groundwater movement increase the bicarbonate [2]. Long-term ingestion of high-fluoride groundwater is the major reason for endemic fluorosis, a condition that affects human health by causing damage to bones and joints (e.g. dental and skeletal flourosis). The existence of this long-term condition in the region indicates that fluoride had a geochemical source present in the aquifer. Common F-bearing minerals (e.g. fluorite, hornblende) were detected in nearest mountain [6]. Groundwater quality assessment studies which we considered above, indicating that the pollution source is dominated over natural process \& municipal solid waste activities in the vicinity of studied area.

\section{References}

[1] Yu N.Vodyanitskii,"Biochemical Processes in soil and groundwater contaminated by leachates from municipal landfills (mini review)", annalys of agrarian science, vol I4, 2016, pp.249-256.

[2] R.M. Kurakalva, K.K. Aradhib, K.Y. Mallela, S. Venkatayogi," assessment of groundwater quality in and around the Jawaharnagar Municipal Solid Waste Dumping site at Greater Heyderabad, Southern India",Procedia Environmental Siences, Vol 35, 2016, pp.328-336. https://doi.org/10.1016/j.proenv.2016.07.013

[3] S.K. Maitia, S.De, T.Hazra, A.Debsarkar, A. Dutta," Characterization of Leachate and Its Impact on Surface and groundwater quality of a closed dumpsite - a case study at dhapa, Kolkata, india", procedia environmental sciences, Vol 35, 2016, pp.391-399.

[4] Magda M. Abd El-Salam, Gaber I. Abu-Zuid," Impact of landfill leachate on the groundwater quality: A case study in Egypt", journal of advanced research, Vol 6, 2015, pp.579-586.

[5] Raffaello Cossu,"Groundwater contamination from landfill leachate: when appearances are deceiving!", waste management, Vol 33, 2013, pp.1793-1794.

[6] Dongmei Han, Xiaoxia Tong, Matthew J. Currell, Guoliang Cao, Menggui Jin, Changshui Tong," Evaluation of the impact of an uncontrolled landfill on surrounding groundwater quality, Zhoukou, China", journal of Geochemical Exploration, Vol 136, 2014, pp.24-39. 